Mr. Pratr then discussed the attitude of chemists to chemical warfare. He said that it has been suggested that chemists should bind themselves together and refuse to have anything to do with the manufacture of material which could be used in warfare. It has been stated that this scheme is not practicable because the chemical profession in most countries is not sufficiently organised and that it would require the co-operation of every nation, whereas the League of Nations itself has shown that it is impossible to get complete agreement on any matter of international policy. Another objection is that, in some countries, every citizen has to do as he is told, and in any event, in war, a man's first duty is to his country. In spite of these objections, Mr. Pratt insisted that the idea is worthy of further consideration because the alternative is so appalling that the chemist might well destroy the civilisation which he hras been instrumental in creating, unless he insists that his inventions are not used for warlike purposes.

\section{National Planning in Industry}

THE need for sound national planning of industrial effort was emphasised in an address delivered before the Birmingham Group of the Institute of Industrial Administration on October 4, by Mr. Harold Macmillan, M.P., president of the Institute. Mr. Macmillan said that we have moved into a new economic society. The conditions of the nineteenth century world have passed away. In the old world Great Britain had great advantages. It was a pioneer nation and the workshop of the world, and on the whole the system was very satisfactory for the greater part of the nineteenth century. In the period preceding the War Great Britain exported capital to foreign countries, financed the market for its own exports and very largely developed the world. That system was very satisfactory while it lasted, but it has largely changed and to-day's problems have arisen almost entirely as the result of that change. The War quickened the pace, and the world has largely industrialised itself, economic nationalism prevails, and the balance of the world has been overthrown. The potential capacity to produce has increased at a rate far more rapid than the market to absorb.

After referring to directions in which the War impeded British industry, Mr. Macmillan said that we have to face realities, and must not be content any longer to try to return to the past. We have to consider on what prosperity depends. It is the maintenance of certain balances-the balance between production and demand, and the monetary balance between the rate of saving and the rate at which savings re-enter a market in the form of investments. He does not think industrialists should be content to go on as industrialists in the same way as they did in the last two or three generations. Industrialists then did not bother themselves very much about monetary standards, but the last ten years have taught them how deeply concerned they are. National self-sufficiency is everywhere increasing. International trade barriers have to be overcome if the standard of living is not to fall.
Unco-ordinated competition among ourselves for the home market weakens resources for obtaining export trade. Capital must contribute by acquiescence in a planned industry, and by demanding high professional standards from management. Management has to contribute by the more efficient co-ordination of functional activities and the elimination of waste in every form, and labour has to contribute by full co-operation resulting from a greater confidence in an industry so planned and conducted.

\section{Friedrich Tietjen, I834-95}

The centenary occurs on October 15 of the birth of the German astronomer Friedrich Tietjen who, in 1881, with Tisserand, E. C. Pickering, Tempel and Gylden, was made a foreign associate of the Royal Astronomical Society. Born in a village in the duchy. of Oldenburg, Tietjen left school at the age of fifteen years to work on his father's farm, but some years later, having relinquished his right to the farm, he was able to attend the Universities of Göttingen and Berlin, and in 1862 at twenty-eight years of age became an assistant under Encke at the Berlin Observatory. Three years later, he became first assistant to Foerster, Encke's successor, and this post he held until 1874. In 1866 he discovered a minor planet, and in the same year, with Albrecht, carried out geodetic operations in connexion with the Mid-European Survey. In 1868 he went to the East Indies with Spörer and Engelman to observe the solar eclipse of August 18. An indefatigable worker and a remarkably facile computer, in 1874 he was made editor of the "Berlin Jahrbuch" and four years later succeeded Bremiker as editor of the "Nautisches Jahrbuch". With Foerster he also managed a school of instruction in scientific computation. He died at the age of sixty years on June 21,1895 , having suffered from ill-health for several years.

\section{Nazi Philosophy and Truth}

IT would be difficult to find a more complete and cynical indifference to freedom of thought and intellectual expression than appears in the speech, as reported in the Times of October 6, delivered by Dr. Frank, the Reich Commissar for Justice, on October 4 to the joint meeting of the Association of German Jurists, the Foreign Political Department of the Nazi Party and the teachers of economics in universities and other places of higher education. Dr. Frank is reported to have said : "as the pursuit of knowledge is the service of truth it must necessarily be service to National-Socialism. We insist that the unity of the philosophy which lies at the basis of National-Socialism must not be challenged by anybody." The exclusive and inviolable identification of philosophic truth with the principles and ideas of a dominant political faction, has a familiar ring which would have provoked no surprise had it come from the mouth of a politician, but its uncompromising terms are startling when uttered by a commissar for justice, who has been responsible for the recent reorganisation of jurists throughout Germany. More was to follow. Dr. Frank went on to say, "Our aim 
must not be originality or novelty in books, but the promotion of national welfare, of national safety, of national wealth and national solidarity. There must be no more battles of theory among you." $\mathrm{He}$ goes on to bid the teachers of law and economics show the way to German intellectual life by their good example. By a strange perversion of logic, policy dictated by political expediency is made the touchstone of truth and teaching, research and speculative thought are to be conditioned by predetermined conclusions, outside the terms of which they may not stray. The restrictions placed on the study of race and the history of culture are evidently now to be extended to jurisprudence and economics.

\section{Clinical Research at Guy's Hospital}

THE governors of Guy's Hospital and the governors of Guy's Hospital Medical School have accepted an invitation from the Medical Research Council to cooperate in the establishment of a new 'unit' for scientific research work in clinical medicine. It has been agreed that the Council will provide the salary of a whole-time director and of his assistants, with the cost of all apparatus and research material used by the unit. For its part, the Hospital will provide suitable laboratory accommodation free of charge, and will place and maintain beds at the disposal of the director : the latter is to be ex officio a member of the visiting staff, with a seat on the Medical Committee and the committees of the Medical School. These arrangements are to be effective for a period of five years in the first instance. Dr. Ronald $\mathrm{T}$. Grant, hitherto working in the service of the Council in the Department of Clinical Research at University College Hospital, London, has been appointed director of the new unit. The invitation was issued to Guy's Hospital by the Medical Research Council in accordance with its general policy of improving the facilities available in Great Britain for the scientific study of disease in the human subject, and with this end in view of increasing the number of higher appointments for whole-time workers in this field. The financial resources which the Council is able to apply to the purpose are those which were released when the senior post formerly maintained by the Council at University College Hospital, and held by Sir Thomas Lewis, received permanent endowment through the generous action of the Rockefeller Foundation.

\section{Electrical Launching Gear for Lifeboats on the Queen Mary}

THE electrical generators of the Queen Mary have a total capacity of about 10,000 kilowatts. There are in addition two 75 kilowatt generating sets driven by Parsons oil engines, which can be used for emergencies. Messrs. Samuel Taylor and Sons, Ltd., of Brierly Hill, Staffs, are supplying all the launching gear for the lifeboats. It includes twenty-four sets of gravity davits and winches. These davits run down inclined trackways carrying the boat with them until they finally reach their outboard position, when the boat is lowered from the davit head into the sea; the whole operation is done without stop- ping, the motive power being gravity. The cradle holding the boat is made in two portions, the carriage and the arm. The two portions run down the track bodily, after which the arm swings out of the carriage until the boat attains the outboard position and the lowering begins. There is no jerk anywhere, the motion being continuous. The movement of the davit is controlled by an electric winch mounted on a deck house. The winches are fitted with patent speed-sustaining brakes which limit the lowering speed of the lifeboats to one foot per second. For raising the lifeboats, after they have been lowered for any reason, such as lifeboat drill, the electric motors are used. Limit switches are provided which check the movement when the davits reach their inboard position and the interlocks make it impossible for the operator to make a mistake.

\section{Mining in Great Britain}

THE thirteenth annual report of the Secretary for Mines for the year 1933 from the Mines Department, which includes as usual the annual report of the Chief Inspector of Mines, has recently been issued (London : H.M. Stationery Office, 1934. 3s. 6d. net). The most important statement in this report is to be found in a review of the British coal-mining industry, which states that "Signs of an improvement in the position of the British coal-mining industry were evident in the latter part of 1933"'. This is a very satisfactory statement as showing that the coal production of the country is at last recovering from the serious slump that has affected it for so long. It must not, however, be supposed that all the difficulties have been overcome, because the report goes on to state that work at the pits was most irregular and that the prices of British coal were slightly lower than in the previous year. It is shown that various trade agreements made with different Governments of Europe have resulted upon the whole in an advantage to the coal trade of Great Britain. It is satisfactory to find that the utilisation of coal and the products derived from it are on the increase, and that serious attention is being given to the question of the use of com. pressed gas for motors. The statement, though now old, that during November 1933 the Secretary for Mines opened the first public filling station for vehicles using compressed gas, is repeated in the report, and it is decidedly interesting to have it thus authoritatively stated. It is obvious from the report that the mining of iron improved during 1933, the increase in the output being more marked in the second half of the year than in the first, as in the case of coal. The remainder of the report of the Secretary for Mines is not of great scientific importance, although his summary of the results obtained in the various testing stations is of a certain amount of public interest. The report of the Chief Inspector of Mines is, as usual, mainly of importance for the numerous tables which it presents.

\section{Weekly Weather Reports}

THE Weekly Weather Report of the Meteorological Office, Air Ministry, for the period February 28, 